\title{
Revisiting the corporate image through service quality and relationship marketing: an empirical evidence from Malaysian and Saudi Arabian Takaful customers
}

\begin{abstract}
Purpose - This study aims to test a proposed model based on a combination of the relationship marketing and service quality dimensions as predictors of corporate image and customer loyalty via corporate reputation in the Takaful context. More importantly, this study compares the Takaful operators' services with the perceived service quality and the relationship marketing from the Malaysian and Saudi Arabian customers' viewpoint.

Design/methodology/approach - A survey-based study conducted through a questionnaire, and the data was collected from Takaful customers (362 Saudi Arabian and 350 Malaysian customers) through an online survey. Structural Equation Modelling (SEM) is employed to test the proposed model. Besides, the perception of Takaful customers between Saudi Arabia and Malaysia is compared through a multi-group analysis.

Findings - Results from the Malaysian context reveal that positive perceptions of service quality PAKSERV dimensions (personalization, reliability, and tangibility) and positive perceptions of relationship marketing dimensions (Islamic ethical behaviour and structural bonds) have a significant influence on the corporate image. Alternatively, in the Saudi Arabian context, results have shown that the positive perceptions of service quality PAKSERV dimensions (assurance and reliability) of service quality and the positive perceptions of the relationship marketing dimensions (Islamic ethical behaviour, structural bonds and financial bonds) have a significant influence on the corporate image. The differences in both countries' results can also enhance the corporate image on corporate reputation, merely in Malaysia. In contrast, corporate reputation is deemed a significant predictor of customer loyalty, represented as valid for both contexts.

Research limitations - The proposed research model tested in Takaful Malaysian and Saudi Arabian can be replicated in other contexts- in terms of country and industry. Moreover, the current study reveals the crucial role of corporate image in forming corporate reputation. Future research could be focussed on the importance of other emotional or affective variables that may be involved in determining corporate reputation. Finally, future studies can be carried with another cultural perspective to have more diversified socio-economic implications.

Practical implications - It is suggested that Takaful operators from both Malaysia and Saudi Arabia need to put maximum effort towards customer loyalty by bringing both the dimensions of service quality and the relationship marketing in compliance with the principles of Islamic business transaction. The findings of the specific dimensions of service quality and relationship marketing will contribute to customers' perceptions of corporate image and reputation in the Takaful industry.

Originality/value - The present study tested a blended facet of customer's overall experience through service quality (PAKSERV) and customer-service provider connectivity (relationship marketing) to predict the corporate image of the highly growing financial marketplace (Takaful). Contextually, this study contributes to delineating the factors (corporate reputation) affecting customer loyalty rather than a customer satisfaction tradition. Significantly, Saudi Arabia and Malaysia were chosen for this study as they are currently the two fast-growing markets for Islamic financial services, especially with regards to the Takaful products and offerings.
\end{abstract}

Keywords Takaful, relationship marketing, customer-service provider connectivity, PAKSERV, corporate image, corporate reputation, customer loyalty, Saudi Arabia, and Malaysia 


\section{Introduction}

Financial products and services are the heart of the economic and social systems. The Islamic financial system is currently the emerging market, with a dynamic set of products and services, which is exceptionally veritable with the Takaful offerings. The Takaful industry has transformed aggressively and expanded rapidly in many major markets, specifically in Islamic countries and countries with a prominently Muslim population. (Hemrit, 2020; Mohy-Ul-Din et al., 2019). Takaful is an Islamic financial service, an alternative to conventional insurance, where it should be devised within the Shariah principles, which include the prohibition of excessive uncertainty (gharar), gambling (maisir), and interest or usury (riba). The most considerable growth of Takaful products and services is observed in the Gulf Cooperation Council (GCC), South East Asia, South Asia, and Africa, respectively (Hassan et al., 2020). Accordingly, Saudi Arabia is leading, followed by Malaysia (Hassan, 2019). The general Takaful dominates the GCC countries (93\%) and MENA (non-GCC, 86\%) compared to the usual growth patterns illustrated by the conventional insurance counterparts. In comparison, the family Takaful leads in South East Asia (74\%) and South Asia (58\%), respectively (Hassan et al., 2020). On the other

hand, Saudi Arabia represents the GCC accounts with the lion's share of 84\%, while Malaysia accounts for $70 \%$ of the market share in Southeast Asia, the largest market in each region and worldwide (Kantakji et al., 2020).

At present, the Takaful operators provide an extensive range of protection plans to satisfy Muslim and non-Muslim customers' diversified needs. Providing Takaful operators in different countries is pertinent because of each country's rules and regulations. More importantly, the products and services need to comply with Islamic law requirements, particularly towards transforming their businesses within Shariah rulings and simultaneously developing corporate cultures and structures in harmony with Islamic values (Alkhan and Hassan, 2020a). Although the experience of patronizing Takaful products and services differs between countries, they must have similar indicators in terms of benchmarking the performance, specifically the two countries Malaysia and Saudi Arabia, representing South East Asia and GCC countries, correspondingly. Hence, the lack of a single model in its implementation has resulted in Takaful operators' different experiences. This study attempts to fill this gap by conducting a comparative analysis between these two most emerging Takaful industry markets.

Based on the increasing growth of Islamic financial services, the Takaful industry becomes more competitive, and their customers can choose discerningly among several Takaful products. Hence, Takaful agents play a substantial role in marketing these products to attain long-term 
relationships between the customers and the Takaful operators (Shukor, 2020). They have focused and paid more attention to provide dynamic and flexible services to meet customer needs. Nevertheless, academic studies on Takaful are inadequate compared to other financial services (Hassan et al., 2020). Therefore, it is essential to examine the perception of customerservice provider connectivity through relationship marketing and service quality, using the measures of PAKSERV and eventually, to discover its effect on corporate image.

The present competition in the financial services market has deep roots in building a good relationship with their customers and their loyalty. Indeed, quality plays an essential role in maintaining everlasting relationships, profitability, and survival of an organization (Aslam and Farhat, 2020). Eventually, quality is rapidly becoming the main factor of customers' patronage towards service providers (Endara et al., 2019). Consequently, previous studies on Takaful have primarily focused on its concept, operations, and adoption. A plethora of research has investigated customers' perceptions and affecting factors towards Takaful products (Ab Rahim and Amin, 2011; Amin, 2012; Kantakji et al., 2020; Muhamat and McIver, 2019; Salman et al., 2020; Alkhan and Hassan, 2020b; Md Husin and Haron, 2020), while others have examined determinants of demand, customer attitudes towards Takaful participation and levels of awareness (Hassan et al., 2018; Maizaitulaidawati and Asmak, 2016).

Even though many service quality studies are conducted in the financial sector, not many can be found in Takaful. Raza et al. (2019) discovered that attitude, subjective norm, and perceived behavioural control are strong predictors of Takaful adoption in Pakistan. Suki and Suki (2019) explored Takaful satisfaction and customer loyalty by examining E-WOM's motives regarding their policy. Contrastingly, it is discovered that compliance together with "sincerity", "personalization", "formality", and "reliability" dimensions of service quality have a significant influence on customers' satisfaction towards Malaysian Islamic banks (Hanafi et al., 2020).

On the other hand, Rehman et al. (2020) investigated Takaful in the Malaysian context and found that service quality dimensions, categorized as tangibility, reliability, and personalization, impact corporate image. Another construct that is the relationship marketing represented by Islamic ethical behaviour and structural bond positively influences the Takaful organizations' corporate image. Shukor (2020) signifies that customers' trust in Takaful agents is due to communication, expertise, and their corporate image. Nevertheless, no previous study has discussed the role of service quality, relationship marketing, corporate image, corporate reputation, and their relationship with customers in the Takaful industry. 
Undoubtedly, cross-cultural research comparing two fertile markets (Saudi Arabia and Malaysia) is still missing and unexplored. The last three decades have witnessed consistent growth of Takaful adoption in Saudi Arabia and Malaysia (according to the statistics mentioned above); thus, some comparisons and investigations are pertinent, especially about the causes of customer loyalty. Therefore, this study responds to Hassan et al. (2020) calls on investigating and describing more factors influencing customers' acceptance of Takaful products and services in more than one country. Furthermore, establishing relationship marketing aspects has yet to be identified, specifically between Malaysian and Saudi Arabian customers' viewpoints. Hence, this study ultimately has specific objectives: (1) analysing the impact of different dimensions of service quality and relationship marketing on the corporate image of Takaful operators through Saudi Arabian and Malaysian customers' perceptions, (2) investigating the relative importance of the corporate image, corporate reputation and customer loyalty of Takaful operators of both countries and (3) examining the significant impact between Malaysian and Saudi Arabian Takaful operators among their customers concerning perceived service quality, relationship marketing, corporate image, corporate reputation, and customer loyalty.

\section{Literature review}

\section{Service quality (PAKSERV model) and corporate image}

Service quality measures customer's expectations and service perceived value (Al-Tamimi and Al-Amiri, 2003). Contemporary thoughts outline that concept of quality is sensitive to culture. Consequently, the PAKSERV model is developed for a non-western context (Raajpoot, 2004) based upon the criticisms on SERVQUAL (Parasuraman et al., 1988). For the South-East Asian and Middle Eastern context, the 'PAKSERV' model (Raajpoot, 2004) for service quality measurement is deemed appropriate to be presented in this study. Scholars should consider the potential effects of cultural differences when evaluating services on an international marketing scale (Raajpoot, 2004).

Raajpoot's (2004) framework PARKSERV is established by revamping service encounter quality at both micro and macro level to understand the variances in judgments. This study considered personalization (customer's evaluation of customization and individualized attention), sincerity (customer's evaluation of the service personnel), and prominent dimensions in place of responsiveness and empathy. To explore service quality in a different culture like Malaysia and Saudi Arabia, a new model was developed. For this purpose, Hofstede (2001) suggested some cultural dimensions. He divided the research into four dimensions: power distance, uncertainty 
avoidance, individualism or collectivism, and masculinity or femininity (Hofstede, 2001). Conversely, in this model of PAKSERV, Raajpoot (2004) added new dimensions: formality, sincerity, and personalization (in place of responsiveness and empathy). Takaful is considered one of the most important financial sectors in Malaysia and Saudi Arabia. As the corporate image concept is relatively new, not many studies in the literature have covered this topic within this region (Al-Mubarak et al., 2019). From our initial research work, we could not find clear evidence of how Takaful operators in Malaysia nor Saudi Arabia apply corporate image, although many studies on the corporate image were conducted in the financial services industry. It appears that corporate image refers to the overall perception in people's minds about a business (Kotler and Barich, 1991). It can be defined as the general attitude and impression in the public's attention about an organization (Balmer and Greyser, 2006) and the views of shareholders, customers, suppliers, media and community (Hatch and Schultz, 2003). Furthermore, the corporate image can influence the customers' decision-making process (Kotler and Gertner, 2002), specifically, those with positive viewpoints through unceasing and constructive promotions, high-quality products and services, besides the use of integrating marketing communication (Hatch and Schultz, 2003).

Moreover, the corporate image may also be signified from the emotional perspectives as "the sum of feelings, ideas, beliefs, knowledge, impressions, and values towards a corporation" (Tran et al., 2015, p. 89). Emotional feelings are psychological thoughts related to the organization's character and the processing of knowledge relating to a firm's characteristics through individuals' experiences and inputs (Nguyen and Leblanc, 2001). Hayward (2005) determined that the elements that embrace the excellent corporate image of the firms, including the Takaful operators, may include its financial performance, the advancement of technology and digitalization, and the reputation of the brand, efficient employees, excellent service quality and exceptional relationship with the community at large.

More importantly, operators of the Takaful need to boost their corporate image, similar to the banking sector, as it is the most effective tool for differentiation and competitive advantage (Van Riel, Lemmink, and Ouwersloot, 2001; Worcester, 2009). Consequently, the corporate image of the operators of Takaful should also incorporate the adherence towards the principles of mua'malah, which include the prohibition of riba' (interest), gharar (uncertainty) and gambling (maisir) (Yusoff, 2002). Consequently, all of these requirements are essential for cooperation among the Takaful contributors in meeting Takaful claims related to events or risks stated in the Takaful certificate (Bank Negara Malaysia, 2019). 
Significantly, the Takaful operators' corporate image should be linked alongside the "worldly activities" such as economic and business, and substantially, needs to fulfil its observance towards Islamic principles. Accordingly, those principles are required to be aligned towards aqidah (belief and faith) and akhlaq (ethics and values), which signifies Islam as having a set of values and principles that are allegiant, resilient and all-embracing (Dusuki, 2008). Therefore, the Takaful operators should aim at thriving to be the prominent service provider for its state-ofthe-art services, people, technology, and shariah-compliant product and services, adhering to its fundamental values and customer-pivotal attributes, and notably, position the customer entirely at the heart of all Takaful activities (Fontaine and Ahmad, 2013).

On the other hand, Osman et al. (2018) conducted a study on the corporate image in Islamic banks in Malaysia and discovered two images related to these organizations; institutional image and performative image. Institutional image is identified as the consequence of the interactions among a person's impression, prevailing beliefs, thoughts, and feelings about an entity (Lin and $\mathrm{Lu}, 2010)$. Furthermore, institutional image is described as a stereotype-driven attribute that links the organizations to positive and negative emotional entities associate with them (Chattalas, Kramer, and Takada, 2008). Conversely, the task environment or performative actions is regarded as "tangible actions to accomplish specific, measurable objectives" (Handelman and Arnold, 1999, p. 35), which is further developed as a "performative image". The facets of Islamic banks' performative image in Malaysia, established by Davies et al. (2004), measure brand personality embrace agreeableness, competence, and entrepreneurship.

On the other hand, institutional image constituents are recognized as Islamic, fair and trustworthy (Osman et al., 2018). In contrast, Saudi Arabian customers perceive their banks' images through their financial prospects, corporate management and corporate communication (Anouze et al., 2018). Therefore, the Takaful operators' corporate image, which has yet to be examined, particularly in Saudi Arabia and Malaysia, should incorporate both views from the conventional aspects and the elements within the principles of Shariah. Consequently, this model was validated in the African cultural context, where all the six dimensions of the PAKSERV model were significant to measure service quality in the banking sector (Saunders, 2008). A study was conducted in a Malaysian Islamic banking context, and it revealed that all components of PAKSERV seemed to influence customer satisfaction, except reliability (Kashif et al., 2016). Additionally, PAKSERV dimensions are widely tested in Islamic banking contexts (Haron et al., 2020). Indeed, the relationships between all the constructs were to identify its impact on the service providers' corporate image. 
Moreover, the element of tangibility, as one of the dimensions of service quality, can be established by corporeal aspects of services in the banking or insurance sector, such as modern equipment, technological advancement, physical facilities, well-dressed employees and visually appealing materials (Parasuraman et al., 1985; Sureshchandar et al., 2002). More importantly, it is established that there is a positive impact of tangibility on customer satisfaction, particularly in the banking sector (Kant et al., 2017). Kant et al. (2017) argued that customer experience about 'tangibility' predicts image, particularly in the banking sector. Thus, customers typically view tangibles as an essential entity, as the values of the organization's general interpretation of SERVQUAL, such as physical facilities, availability, adequacy of equipment, and a bank's appearance's employees. They can also gauge the bank's premises or the bank's staff (Olorunniwo and Hsu, 2006). Eventually, the banking customer service's pleasantness with a high-quality sense of physical facilities, with a positive outlook, is regarded as a satisfactory banking image (Nguyen and Leblanc, 1998). Therefore:

$H_{1}$ : Positive customer experience of Tangible aspects is certainly related to the corporate image of Takaful operators in Malaysia $\left(H_{1 a}\right)$ and Saud Arabia $\left(H_{1 b}\right)$

Secondly, reliability is regarded as the organization's promise to deliver the services at the right time, solve issues and provide error-free transactions (Westbrook, 1981). Although facets of reliability are committed to personal interaction and signify service quality in a retail setting, reliability is explicitly related to managing problems (Dabholkar et al., 1996). Reliability refers to providing the promised services accurately. The Holy Quran has outlined the obligation of keeping promises; "And fulfil the covenant of Allah when you have taken it, [O believers], and do not break oaths after their confirmation while you have made Allah, over you, a witness. Indeed, Allah knows what you do" [An-Nahl: 91]. Consequently, Takaful's reliability goes beyond the service offerings, as it needs to keep track of greater transparency and oversight from different forms of supervisory and self-regulatory organizations. Thus, it can be argued that:

$\mathrm{H}_{2}$ : Positive customer experience of Reliability is certainly related to the corporate image of Takaful operators in both Malaysia $\left(\mathrm{H}_{2 a}\right)$ and Saudi Arabia $\left(H_{2 b}\right)$

Thirdly, assurance refers to the employees' ability and competency to inspire customers (Parasuraman et al., 1985). It is also related to how the customer feels secure concerning financial and banking services (Ennew and Waite, 2013). Although there is limited literature on 
the effect of customers' perception of service assurance on corporate image, few studies provided support (Munusamy et al., 2010; Kant and Jaiswal, 2017). Therefore:

$H_{3}$ : Positive customer experience of Assurance is certainly related to the corporate image of Takaful operators in both Malaysia $\left(\mathrm{H}_{3 a}\right)$ and Saudi Arabia $\left(H_{3 b}\right)$

Fourthly, Rajpoot (2004) defined sincerity as the service personnel who accentuates "genuine" and originality. Accordingly, it is found that customers' existing negative perceptions towards an organization adversely influence their reactions to corporate image (Becker-Olsen and Hill, 2006). Further, Yoon et al. (2006) also stated that some branding activities linked to the corporate image might reduce the perceived levels of the organization's sincerity and further reinforce their existing negative feelings about the organization's unethical conduct. Further, Yoon et al. (2006) added that some branding activities linked to the corporate image might encourage the perceived levels of the organization's honesty and sincerity. Hence,

$\mathrm{H}_{4}$ : Positive customer experience of sincerity is certainly related to the corporate image of Takaful operators in both Malaysia $\left(\mathrm{H}_{4 a}\right)$ and Saudi Arabia $\left(\mathrm{H}_{4 b}\right)$

Fifth, personalization denotes a customer's evaluation of individualized attention (Rajpoot, 2004). Personalization has been presumed to affect satisfaction and loyalty (Coelho and Henseler, 2012). Further, customers prefer personalized services, especially when getting additional advice from the banking personnel before buying and using the products to minimize the various risks associated with those services (Kashif et al., 2016). In Takaful's context, personalization plays an integral role in developing a corporate image. Many Takaful operators, including Syarikat Takaful Malaysia Keluarga Berhad (2018), are keen on developing protection solutions with a high degree of personalization that requires them to incorporate digital capabilities into the business model directly. More importantly, the adoption of digital transformation with personalized mechanisms becomes a priority to many Takaful operators, mainly to keep up with the fast-paced development of insurance technology and offer a differentiated service experience. Huang et al. (2014) conferred the role of personalized service while scrutinizing the impact of service quality on corporate image. They concluded that organizations that provide personalized services are likely to exude a positive corporate image. Thus, the following is hypothesized: 
$H_{5}:$ Positive customer experience of personalization is certainly related to

the corporate image of Takaful operators in both Malaysia $\left(H_{5 a}\right)$ and

Saudi Arabia $\left(H_{5 b}\right)$

\section{Relationship marketing and corporate image}

Relationship marketing is an economic, psychological, emotional, or physical attachment developed through interaction (Taleghani et al., 2011). According to Nguyen and Leblanc (2001), corporate image is the characteristics of an organization, similar to its name, building, diversity of goods/services, and customer commination. On the contrary, relationship marketing is one of the marketing approaches that concentrate on customer orientation to create longlasting relationships (Berry, 1995). Marketers have to be customer-focused and provide services perceived as "Islamic", especially with the current challenging market environment and customer demands for quality services (Hassan et al., 2018).

Indeed, ethics seem to be the main agenda of many marketing issues (Piercy and Lane, 2007), but not many of these studies have included religious elements in their realm (Muhamad and Mizerski, 2010). In terms of developing ethical standards in an organization, certainly, it can help focus their business conscience towards social responsibility and moral obligation, rather than on gaining excessive profitability. More importantly, ethical behaviour is pertinent as it connects to corporate image, which is the customers' perceptions of pleasant personalities, society's prosperity, and happiness (Rehman et al., 2019; Sufi et al., 2020). It is reasoned that services allegedly affect corporate image positively, and customers build positive perceived value and image of that service. Therefore,

$H_{6}$ : Positive customer experience of Islamic ethical behaviour is certainly related to Takaful operators' corporate image in Malaysia $\left(H_{6 a}\right)$ and Saudi Arabia $\left(H_{6 b}\right)$.

Social bonds can help the organization develop its relationships with customers (Berry, 1995). Social bonding serves as a tool for measuring a long-term relationship at the operational level (Kim et al., 2020), establishing integrated communications (Rehman et al., 2019; Mohy-Ul-Din et al., 2019). Huang et al. (2014) investigated the connection between relationship bonds, quality and brand loyalty. They found that relationship bonds are of great importance in enhancing relationship quality and brand loyalty. In reality, the social bond is based on establishing close ties with stakeholders through social interaction, where they can acquire psychological gains (Gwinner et al., 1998), specifically associated with a person's commitment through high 
interpersonal orientation. More importantly, interaction among service providers delivers psychological benefits by forming intimacy and trust (Rodríguez and Wilson, 2002). Service providers, who have established positive social relations, become emotionally immersed with the customers, as they may continuously embrace a sense of belonging with the organization (Wang et al., 2014).

Therefore, from the standpoint of service providers, the social bond is the corporate effort to establish relations and create value for stakeholders (Wang et al., 2014). Social bonds provide customers with care and openness, translating to mutual understanding and engagement between both parties (Chiu et al., 2005). The corporate image will capture those positive mechanisms of emotions through the reinforcement of social bonds. There is substantial evidence that customers tend to favour organizations that provide particular attractiveness that bonds the two parties through values and social support. The social bonds created through an affective or emotional element of attitude tend to develop the overall positive image in customers' minds (Alwi and Ismail, 2013). More importantly, the customer-service provider relationship is deeply rooted within social values, socialization, and connectivity. Hence, social bonds conceivably trigger positive customer perception of corporate image (Rehman et al., 2019). Consequently,

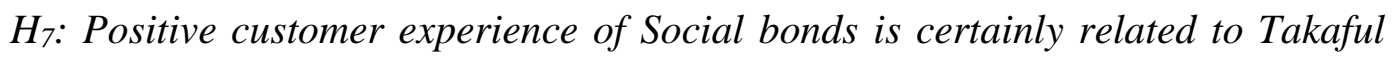
operators' corporate image in Malaysia $\left(H_{7 a}\right)$ and Saudi Arabia $\left(H_{7 b}\right)$.

Structural bonds are considered an economic-based task that links a buyer and a seller in a business relationship through mutual economic, strategic, technological, or organizational benefits (Rodríguez and Wilson, 2002). The service providers may attempt to retain customers by delivering priceless services that are inaccessible from other sources, including providing integrated services through their business associates (Chiu et al., 2005), or by offering innovative channels, integrated database or two-way information exchange technologies (Dibb and Meadows, 2001). Some studies have ranked this type of bonding as the highest, as it provides an opportunity for organizations to gain a competitive advantage (Peltier and Westfall, 2000). The value delivered by service providers attached to the structural bond's perception, especially those developed through promotional strategies, concurrently contributes to corporate image. Thus, structural bonds can be developed by suggesting their respective solutions (Shammout, 2018; Lee and Han, 2019). Thus, it can be proven that structural bonds can generate a sense of belongingness towards the corporate image. Subsequently, 
$H_{8}:$ The positive customer experience of structural bonds is certainly related to Takaful operators' corporate image in Malaysia $\left(H_{8 a}\right)$ and Saudi Arabia $\left(H_{8 b}\right)$.

Financial bonds refer to providing monetary benefits through the relationship of formation strategy (Berry, 1995). Some examples may include organizations providing incentives like discounts or financial dependence to customers to form relationships (Hsieh et al., 2005). Financial benefits play a pivotal role in forming an enduring relationship between customer and organization (Gwinner et al., 1998). Takaful contract and business practice will only form a harmony with the Islamic concept of mutual co-operation. The transaction is operated based on Islamic principles to ensure financial security against the participant's unexpected future material risk (Matsawali et al., 2012). Accordingly, in the Takaful industry, the Takaful agent is deemed as a financial consultant. In practice, they are liable to inform and advise the customer about future financial preparation by proposing a suitable Takaful product based on their needs. This responsibility should be based on Islamic ethics, which will eventually draw their relationship closer to the customer. In this regard, the relationship's nature depends on the Takaful agent (Salleh et al., 2013). Previous studies have proven a positive relationship between financial benefits and emotions that foster relational aspects between the interactions and enhance its relationship quality and brand loyalty (Huang et al., 2014). Thus:

$H_{9}:$ Positive customer experience of financial bonds is certainly related to Takaful operators' corporate image in Malaysia $\left(\mathrm{H}_{9 a}\right)$ and Saudi Arabia $\left(\mathrm{H}_{9 b}\right)$.

\section{Corporate image and corporate reputation}

As far as corporate image is concerned, positive attributes within the structural bond can attract new customers and retain loyal ones. Structural bonds are projected onto the corporate image, and over a period, they transform within corporate reputation through corporate communication activities (Abdullah et al., 2013). Eventually, customers can create and change their impression of the corporation (Bravo et al., 2009; Hussain et al., 2020) based on their structural bonds' perceptions. The corporate image can also be attained through financial bonds using loyalty programs, special price offers, and award points. Indeed, financial promotions can improve customers' perceptions of utilitarian value and increase their purchases' acquisition utility (Chandon et al., 2000). Social bonds created through affective or emotional elements of attitude tend to develop that overall positive image in consumers' minds (Alwi and Ismail, 2013). 
Consequently, these promotion types develop and further transfer the brand's essence and corporate identity to build a favourable image (Abdullah et al., 2013; Melewar et al., 2017). Thus, customers can create and change their impressions based on their perceptions of the organization's marketing promotions. One of the most important factors influencing customer purchase and customer behaviour is the corporate image, which results from an assessment process (Gray and Balmer, 1998). On the other hand, corporate reputation is introduced as a perception of quality associated with the corporate name (Gray and Balmer, 1998), indicating its attractiveness to customers compared to its rivals (Shamma, 2012). A positive corporate reputation can be constructed through regular communication of a positive corporate image (Alessandri, 2001). Thus, the organization can improve its reputation when it constructs and communicates its corporate identity to its stakeholders (Dowling, 2004) through the favourable corporate image (Melewar et al., 2017).

The corporate image consists of two dimensions, namely functional and emotional. The functional component is based on tangible attributes, which are merely measurable. Compared to this dimension, the emotional component is related to psychological features, such as behaviour (Nguyen and Leblanc, 2001). Generally, corporate image and reputation are generated through customers' perspectives, feelings, attitudes, beliefs, and experiences towards an organization. A bright and powerful corporate image can reflect its corporate reputation (Rehman et al., 2019). De Leaniz and del Bosque (2016) outlined that functional and emotional image positively influences corporate reputation in this vein. Shukor (2020) also indicated that a favourable image is a powerful tool in building a sincere relationship and customers' perception of an organization and can increase customer loyalty in Takaful agents (Shukor, 2020). Gray and Balmers'(1998) work is considered a seminal contribution to the relationship between corporate image and corporate reputation. Thus:

H10: Corporate image is positively related to Takaful operators' corporate reputation in Malaysia $\left(H_{10 a}\right)$ and Saudi Arabia $\left(H_{10 b}\right)$.

\section{Corporate reputation and customer loyalty}

Loyalty refers to a deep and strong commitment to repurchase product or service of the same brand, despite potential competitors' marketing efforts (Oliver, 1999). It is proven that corporate image directly (Nguyen and Leblanc, 2001) and indirectly (Shukor, 2020) affects customer loyalty. Previous studies provide enough theoretical support to the argument about the positive impact of corporate reputation on customer loyalty (Rehman et al., 2019; De Leaniz and del 
Bosque Rodríguez, 2016; Lai, 2019). However, there is limited evidence about this association in the context of the Takaful industry. Many researchers proposed an excellent corporate image and reputation to help develop customer loyalty (Helm and Tolsdorf, 2013, Walsh et al., 2009). Indeed, a persevering, promising corporate image ensures a favourable reputation and develops positive attitudes in customers toward the organization (Balmer et al., 1997). Therefore, the current study postulates that:

$H_{11}$ : Corporate reputation is positively related to Takaful operators' customer loyalty in Malaysia $\left(H_{11 a}\right)$ and Saudi Arabia $\left(H_{11 b}\right)$.

\section{Methodology}

\section{Sample}

This study aims at testing a proposed model based on a combination of relationship marketing and service quality dimensions as the predictors of Takaful operators' corporate image in Malaysia and Saudi Arabia. These countries were selected for this study due to the aggressive growth of the Takaful marketplace. The target population for the current study is chosen among the customers of Takaful operators in both countries. Since the population is geographically distributed, the best choice was to conduct an online survey, which was cost-effective, timeeffective, and, more importantly, covered the Takaful customers' entire population across these countries. Thus, the data was gathered through a structured questionnaire, and a non-probability purposive sampling technique was applied (Hassan and Abbas, 2019). According to Hair et al. (2017) and Hair et al. (2019), the "ten times rule" is an appropriate tool to select sample size for Partial Least Squares Structural Equation Modelling (PLS-SEM). Based on this rule, the sample size of 370 respondents was considered appropriate for Saudi Arabia and Malaysia (Hair et al., 2019). However, 362 responses from Saudi Arabian and 350 responses from the Malaysian Takaful customers were received.

\section{Instrument development and data collection}

The questionnaire is divided into demographic information; gender, age, education, and occupation, to assess data diversification and items considering all the variables, such as PAKSERV dimensions ('tangibility', 'reliability', 'assurance', 'sincerity', and 'personalization' all the items are adapted from Rajpoot (2004). Additionally, relationship marketing constructs are composed of Islamic ethical behaviour, social bonds, structural bonds, financial bonds, 
corporate image, and customer loyalty, generally based on Nam (2008). The study measures all variables based on the five-point Likert scales, ranging from "strongly disagree" to "strongly agree".

To collect quantitative data from the selected countries, the questionnaires used were developed based on three languages, i.e., "Malay, English, and Arabic" so that participants could understand the items and correctly respond to them. We adopted a rigorous process to translate the questionnaire by native bilingual experts. After Takaful managers and content experts verified the pre-tested questions, an online survey was conducted. Data was then analyzed with the help of SPSS and SmartPLS. The analysis was applied to 712 responses through which demographic analysis, descriptive analysis, reliability, convergent validity, discriminant validity, loadings, and path analysis were completed. Moreover, the multi-group analysis (MGA) was also employed to assess the significant difference between the results of both populations (Saudi Arabia and Malaysia) through the "Parametric Test".

\section{Results}

\section{Sample characteristics}

To assess respondents' profile, frequency analysis was completed in SPSS through which the number of respondents against each demographic characteristic was found. Table I shows the results of the demographic analysis. The sample mix (Malaysian - 350 and $40 \%$ males, Saudi Arabian - 362, 46\% males). It means that the current sample includes a higher representation of female Takaful customers than male customers in both countries. It seems possible that this skewness is due to involving more females in using Takaful services in Malaysia and Saudi Arabia, so Takaful operators have more female customers in those countries. Out of 350 Malaysian and 362 Saudi Arabian customers, 65\% were aged between 31 and 59. In terms of occupation, $42 \%$ of Saudi Arabian Takaful customers are employed in private companies, and $30 \%$ out of 350 Malaysian Takaful customers were from public companies.

Table I. Sample profile

\begin{tabular}{llcccc}
\hline \multirow{2}{*}{ Demographic Variable } & Attribute & \multicolumn{2}{c}{ Malaysia $(n=350)$} & \multicolumn{2}{c}{ Saudi Arabia $(n=362)$} \\
& & $\mathrm{N}$ & $\%$ & $\mathrm{~N}$ & $\%$ \\
\cline { 3 - 5 } Gender & Male & 140 & 40 & 167 & 46 \\
Total & Female & 210 & 60 & 195 & 54 \\
& & 350 & 100 & 362 & 100
\end{tabular}




\begin{tabular}{llcccc} 
& Under 30 & 81 & 23 & 30 & 8 \\
Age & $31-59$ & 229 & 65 & 235 & 65 \\
Total & 60 years or older & 40 & 11 & 97 & 27 \\
& & 350 & 100 & 362 & 100 \\
& & & & & \\
Occupation & Student & 8 & 2 & 3 & 1 \\
& Private Employee & 79 & 23 & 152 & 42 \\
Total & Public Employee & 106 & 30 & 112 & 31 \\
& Others & 157 & 45 & 95 & 26 \\
& & 350 & 100 & 362 & 100 \\
\hline
\end{tabular}

\section{Collinearity}

The "Variance Inflation Factor" (VIF) is generally used to check multicollinearity. Table II provides a summary of results found collinearity which is less than 5 , and it is aligned with the "rule of thumb", as highlighted by Hair et al. (2017). It means that no multicollinearity exists in the current data. The comparative values of VIF for KSA and Malaysian data have been presented in Table II.

Table II. Collinearity

\begin{tabular}{lcc}
\hline \multirow{2}{*}{ Constructs } & \multicolumn{2}{c}{ VIF } \\
\hline & Malaysia & Saudi Arabia \\
\cline { 2 - 3 } Assurance & 1.34 & 1.05 \\
Personalization & 1.50 & 1.03 \\
Reliability & 1.21 & 1.08 \\
Sincerity & 1.39 & 1.04 \\
Tangibility & 1.14 & 1.05 \\
Social Bonds & 1.80 & 1.04 \\
Structural Bonds & 1.57 & 1.05 \\
Financial Bonds & 1.40 & 1.09 \\
Islamic Ethical Behaviour & 1.43 & 1.03 \\
Corporate Image & 1.00 & 1.00 \\
Corporate Reputation & 1.00 & 1.00 \\
\hline (Malaysia $(n)=350$, Saudi Arabia $(n)=362)$ &
\end{tabular}

\section{Reliability and validity}

After assessing the collinearity in the data, the reliability and validity were analysed, for which the critical indicators of composite reliability (CR) and average variance extracted (AVE) were computed and assessed. Table III indicates the results of construct reliability and validity for 
both categories of data, both Saudi Arabia and Malaysia. The critical ratio was used instead of Cronbach's alpha to measure the reliability of constructs because it is the more efficient and unbiased measure of construct reliability (Peterson and Kim, 2013), and the CR values are in the threshold (higher than 0.7). It means that the current questionnaire has proven to be a good measure of those variables within Malaysia's context. The AVE against each variable should be greater than 0.5 for the validity of the data. It is indicated in Table III that the AVE against all variables included in this study is less than 0.5. Thus, Saudi Arabia and Malaysia's data represent both the construct and convergent validity values (Hair et al., 2017).

Table III. Construct reliability and validity

\begin{tabular}{|c|c|c|c|c|c|c|c|}
\hline \multirow[t]{2}{*}{ Constructs } & \multirow[t]{2}{*}{ Items } & \multicolumn{3}{|c|}{ Malaysia } & \multicolumn{3}{|c|}{ Saudi Arabia } \\
\hline & & Loadings & AVE & $\mathrm{CR}$ & Loadings & AVE & $\mathrm{CR}$ \\
\hline \multirow[t]{2}{*}{ Assurance } & AS4 & 0.80 & \multirow[b]{2}{*}{0.64} & \multirow[b]{2}{*}{0.78} & 0.70 & \multirow[b]{2}{*}{0.58} & \multirow[b]{2}{*}{0.70} \\
\hline & AS5 & 0.80 & & & 0.82 & & \\
\hline \multirow[t]{2}{*}{ Personalization } & PR3 & 0.81 & \multirow[b]{2}{*}{0.63} & \multirow[b]{2}{*}{0.77} & 0.71 & \multirow{2}{*}{0.67} & \multirow{2}{*}{0.72} \\
\hline & PR4 & 0.77 & & & 0.92 & & \\
\hline \multirow[t]{3}{*}{ Reliability } & RE1 & 0.72 & \multirow{3}{*}{0.57} & \multirow{3}{*}{0.72} & 0.69 & \multirow{3}{*}{0.56} & \multirow{3}{*}{0.76} \\
\hline & RE2 & 0.70 & & & 0.73 & & \\
\hline & RE3 & 0.80 & & & 0.82 & & \\
\hline \multirow[t]{2}{*}{ Sincerity } & SN2 & 0.71 & \multirow[b]{2}{*}{0.63} & \multirow[b]{2}{*}{0.77} & 0.95 & \multirow{2}{*}{0.71} & \multirow{2}{*}{0.73} \\
\hline & SN3 & 0.87 & & & 0.72 & & \\
\hline \multirow[t]{2}{*}{ Tangibility } & TAN2 & 0.86 & \multirow[b]{2}{*}{0.60} & \multirow[b]{2}{*}{0.76} & 0.81 & \multirow{2}{*}{0.72} & \multirow{2}{*}{0.74} \\
\hline & TAN3 & 0.67 & & & 0.89 & & \\
\hline \multirow[t]{4}{*}{ Social Bonds } & SB1 & 0.67 & & & 0.69 & & \\
\hline & SB2 & 0.76 & 0.51 & 0.81 & 0.72 & 0.53 & 0.80 \\
\hline & SB3 & 0.79 & & & 0.71 & & \\
\hline & SB4 & 0.62 & & & 0.79 & & \\
\hline Structural Bonds & STB2 & 0.63 & & & 0.72 & & \\
\hline & STB3 & 0.79 & 0.52 & 0.76 & 0.70 & 0.59 & 0.77 \\
\hline & STB4 & 0.74 & & & 0.88 & & \\
\hline Financial Bonds & FB1 & 0.69 & & & 0.74 & & \\
\hline & FB2 & 0.81 & 0.53 & 0.77 & 0.81 & 0.55 & 0.76 \\
\hline & FB3 & 0.69 & & & 0.69 & & \\
\hline Islamic Ethical Behaviour & IEB5 & 0.72 & & & 0.71 & & \\
\hline & IEB6 & 0.76 & 0.52 & 0.77 & 0.85 & 0.59 & 0.77 \\
\hline & IEB7 & 0.69 & & & 0.74 & & \\
\hline Corporate Image & $\mathrm{CI} 2$ & 0.78 & & & 0.72 & 064 & 071 \\
\hline & $\mathrm{CI} 3$ & 0.81 & 0.63 & 0.78 & 0.88 & 0.04 & 0.11 \\
\hline Corporate Reputation & CR3 & 0.71 & & & 0.70 & & \\
\hline & CR4 & 0.80 & 0.51 & 0.76 & 0.79 & 0.59 & 0.78 \\
\hline & CR5 & 0.68 & & & 0.82 & & \\
\hline
\end{tabular}




\begin{tabular}{llllllll}
\hline Customer Loyalty & CL1 & 0.67 & & & 0.76 & & \\
& CL2 & 0.70 & 0.54 & 0.78 & 0.82 & 0.64 & 0.79 \\
& CL3 & 0.73 & & & 0.83 & & \\
\hline
\end{tabular}

$($ Malaysia $(n)=350$, Saudi Arabia $(n)=362)$

\section{Structural Equation Modeling (SEM) and Multi-Group Analysis (MGA)}

To assess and compare the impact of perceptions of PAKSERV dimensions and customerservice provider connectivity through relationship marketing, corporate image, corporate reparation and customer loyalty from Malaysian and Saudi Arabian Takaful operators, MGA was completed through Smart PLS. Figure I illustrates the structural model of the current study for Malaysia's data, while Figure II presents the structural model for Saudi Arabia. Hence, these two models were tested in the context of Saudi Arabia and Malaysia. Path coefficients (Table IV) show that an increase in positive perceptions of service 'personalization' $\left(\mathrm{H}_{5 \mathrm{a}}\right.$, $\mathrm{p}$-value $\left.<0.05\right)$, 'tangibility' $\left(\mathrm{H}_{1 \mathrm{a}}, \mathrm{p}\right.$-value $\left.<0.05\right)$, 'reliability' $\left(\mathrm{H}_{2 \mathrm{a}}, \mathrm{p}\right.$-value $\left.<0.05\right)$, 'Islamic ethical bonds' $\left(\mathrm{H}_{6 \mathrm{a}}\right.$, p-value $<0.05)$, and 'structural bonds' $\left(\mathrm{H}_{8 \mathrm{a}}\right.$, $\mathrm{p}$-value $\left.<0.05\right)$ causes an increase in the 'corporate image' of Takaful operators in Malaysia. However, the results for Saudi Arabian Takaful customers are different, customer positive perceptions of service 'reliability' $\left(\mathrm{H}_{2 \mathrm{~b}}\right.$, p-value < $0.05)$, 'assurance' $\left(\mathrm{H}_{3 b}, \mathrm{p}\right.$-value $\left.<0.05\right)$, 'Islamic ethical bonds' $\left(\mathrm{H}_{6 \mathrm{~b}}\right.$, $\mathrm{p}$-value $\left.<0.05\right)$, 'financial bonds' $\left(\mathrm{H}_{9 \mathrm{~b}}, \mathrm{p}\right.$-value $\left.<0.05\right)$, and 'structural bonds' $\left(\mathrm{H}_{8 \mathrm{~b}}\right.$, p-value $\left.<0.10\right)$ are enhancing the 'corporate image'.

On the other hand, Malaysian customer perception about 'corporate image' increases 'corporate reputation' renders support for $\mathrm{H}_{10 \mathrm{a}}(\mathrm{p}<0.05)$, while results from Saudi Arabia did not supported $\mathrm{H}_{10 \mathrm{~b}}(\mathrm{p}>0.10)$. Results are consistent from both contexts for $\mathrm{H}_{11 \mathrm{a}}$ and $\mathrm{H}_{11 \mathrm{~b}}(\mathrm{p}<0.05)$ that translate into customer positive perception about 'corporate reputation', leading to 'customer loyalty'. 


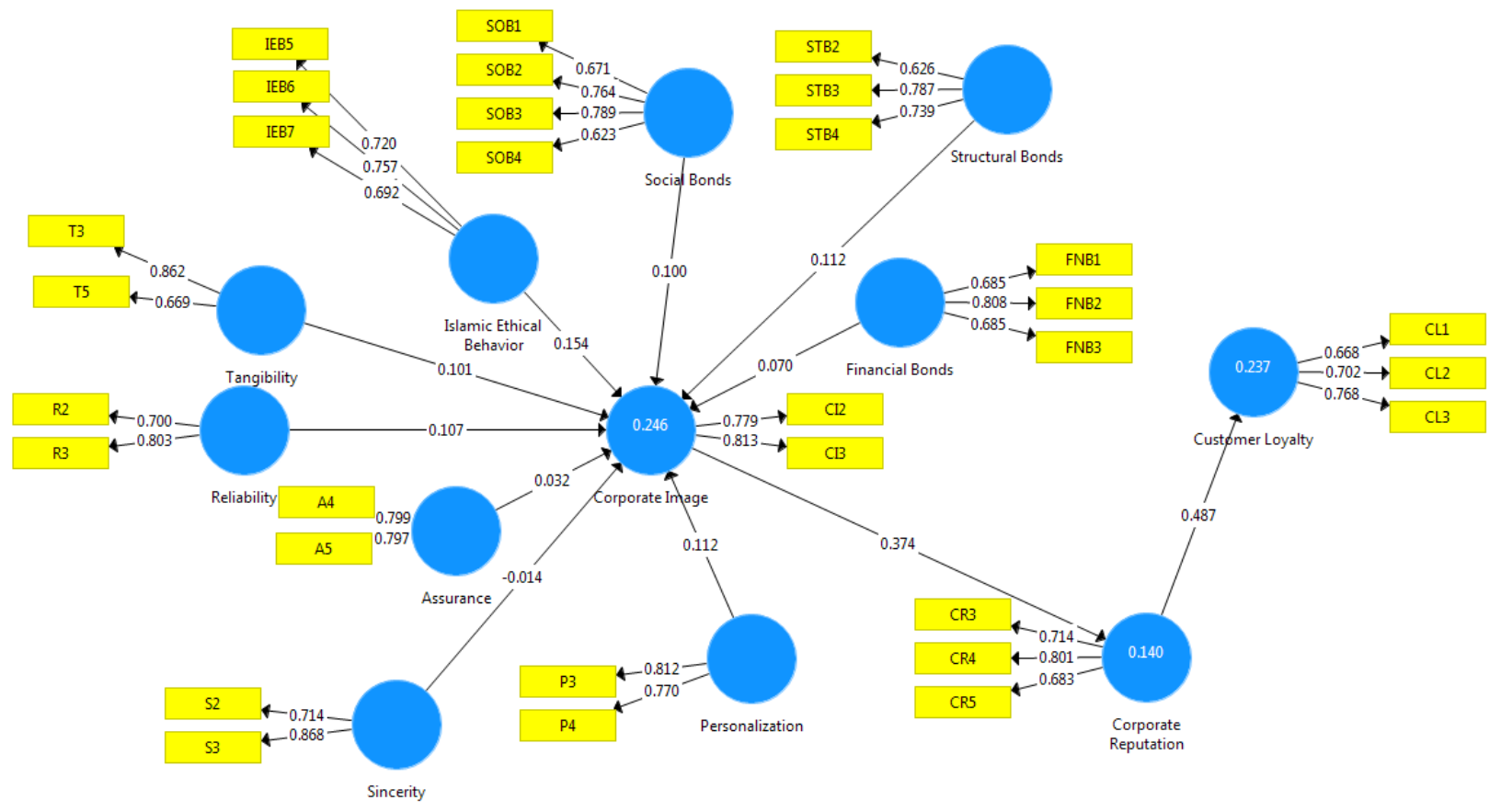

Figure I. Structural Model (Malaysia)

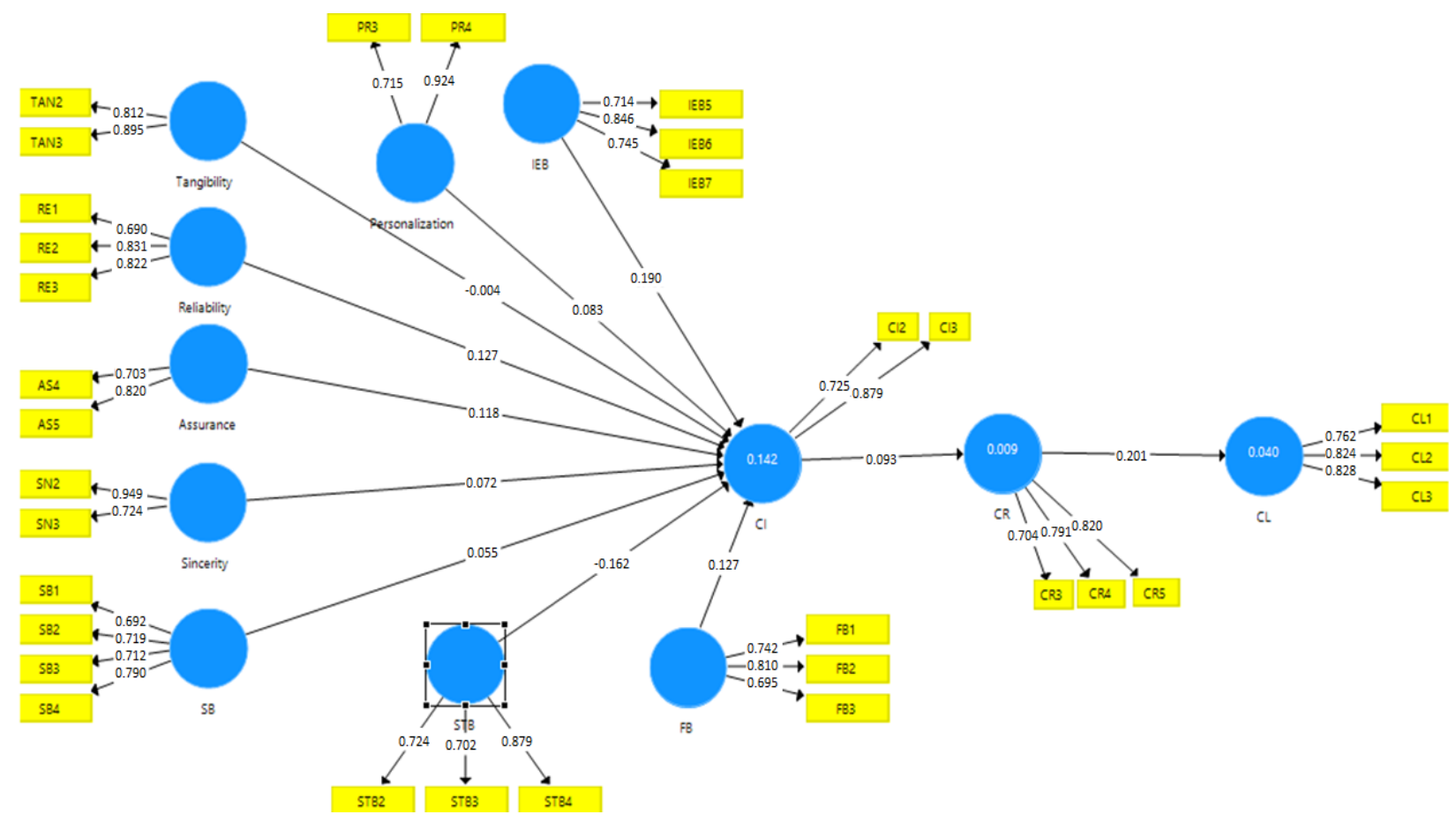

Figure II. Structural Model (Saudi Arabia) 
Table IV. Path Analysis for Saudi Arabia and Malaysia

\begin{tabular}{|c|c|c|c|c|c|c|c|c|c|}
\hline Hypothesis & Path & $\begin{array}{l}\text { Path Coefficient } \\
\text { (Malaysia) }\end{array}$ & $\begin{array}{l}\text { Path Coefficient } \\
\text { (Saudi Arabia) }\end{array}$ & $\begin{array}{l}\text { t-Values } \\
\text { (Malaysia) }\end{array}$ & $\begin{array}{l}\text { t-Values } \\
\text { (Saudi } \\
\text { Arabia) } \\
\end{array}$ & $\begin{array}{l}\text { p-Values } \\
\text { (Malaysia) }\end{array}$ & $\begin{array}{c}\text { p-Values } \\
\text { (Saudi Arabia) }\end{array}$ & $\begin{array}{c}\text { Hypothesis } \\
\text { (Malaysia) } \\
\text { (a) }\end{array}$ & $\begin{array}{c}\text { Hypothesis } \\
\text { (Saudi Arabia) } \\
\text { (b) }\end{array}$ \\
\hline $\mathrm{H} 1$ & $\mathrm{TAN} \rightarrow \mathrm{CI}$ & 0.10 & 0.00 & 2.05 & 0.05 & 0.02 & 0.96 & Supported & Not supported \\
\hline $\mathrm{H} 2$ & $\mathrm{RE} \rightarrow \mathrm{CI}$ & 0.10 & 0.13 & 2.35 & 2.01 & 0.00 & 0.05 & Supported & Supported \\
\hline H3 & $\mathrm{AS} \rightarrow \mathrm{CI}$ & 0.03 & 0.12 & 0.50 & 1.95 & 0.30 & 0.05 & Not Supported & Supported \\
\hline $\mathrm{H} 4$ & $\mathrm{SN} \rightarrow \mathrm{CI}$ & -0.01 & 0.07 & 0.25 & 0.91 & 0.40 & 0.36 & Not Supported & Not supported \\
\hline H5 & $\mathrm{PR} \rightarrow \mathrm{CI}$ & 0.11 & 0.08 & 1.89 & 1.07 & 0.02 & 0.29 & Supported & Not supported \\
\hline H6 & $\mathrm{IEB} \rightarrow \mathrm{CI}$ & 0.15 & 0.19 & 2.48 & 4.01 & 0.00 & 0.00 & Supported & Supported \\
\hline $\mathrm{H} 7$ & $\mathrm{SB} \rightarrow \mathrm{CI}$ & 0.10 & 0.06 & 1.60 & 0.74 & 0.15 & 0.46 & Not Supported & Not supported \\
\hline H8 & $\mathrm{STB} \rightarrow \mathrm{CI}$ & 0.11 & -0.16 & 1.82 & 1.69 & 0.03 & 0.10 & Supported & Supported \\
\hline H9 & $\mathrm{FB} \rightarrow \mathrm{CI}$ & 0.07 & 0.13 & 1.16 & 2.09 & 0.12 & 0.04 & Not Supported & Supported \\
\hline H10 & $\mathrm{CI} \rightarrow \mathrm{CR}$ & 0.37 & 0.09 & 6.80 & 1.35 & 0.00 & 0.18 & Supported & Not supported \\
\hline $\mathrm{H} 11$ & $\mathrm{CR} \rightarrow \mathrm{CL}$ & 0.48 & 0.20 & 10.03 & 2.58 & 0.00 & 0.01 & Supported & Supported \\
\hline
\end{tabular}

Note: $p$-value <0.05; p-value < 0.10

Constructs: AS (assurance), CI (corporate image), PR (personalization), RE (reliability), SN (sincerity),

TAN (tangibility), SB (social bonds), STB (structural bonds), CR (corporate reputation), FB (financial bonds),

IEB (Islamic ethical behaviour), CL (customer loyalty)

To compare the results of both groups (Malaysia and Saudi Arabia), the MGA parametric test has been used (Table V) to determine the significance of the difference of these results. Table V shows a significant difference between Saudi Arabia and Malaysia's results regarding the impact of corporate image on corporate reputation, corporate reputation on customer loyalty, and the perceptions of structural bonds on the corporate image of Takaful operators. On the other hand, other differences in findings between Saudi Arabia and Malaysia are not significant. Hence, it can be found that the impacts of corporate image on corporate reputation, corporate reputation on customer loyalty, and perceptions of structural bonds on the corporate image of Takaful operators significantly differ between Saudi Arabia and Malaysia (p-value $<0.1)$. 
Table V. Multi-Group Analysis - Parametric Test (Malaysia vs Saudi Arabia)

\begin{tabular}{ccccc}
\hline Hypothesis & Path & Path Coefficients-difference & t-Value & p-Value \\
\hline H1 & TAN $\rightarrow$ CI & 0.09 & 0.97 & 0.34 \\
H2 & RE $\rightarrow$ CI & 0.03 & 0.40 & 0.69 \\
H3 & AS $\rightarrow$ CI & 0.07 & 0.86 & 0.39 \\
H4 & SN $\rightarrow$ CI & 0.09 & 0.90 & 0.37 \\
H5 & PR $\rightarrow$ CI & 0.03 & 0.36 & 0.72 \\
H6 & IEB $\rightarrow$ CI & 0.04 & 0.53 & 0.60 \\
H7 & SB $\rightarrow$ CI & 0.05 & 0.47 & 0.64 \\
H8 & STB $\rightarrow$ CI & $\mathbf{0 . 2 8}$ & $\mathbf{2 . 3 9}$ & $\mathbf{0 . 0 2}$ \\
H9 & FB $\rightarrow$ CI & 0.06 & 0.66 & 0.51 \\
H10 & CI $\rightarrow$ CR & $\mathbf{0 . 2 8}$ & $\mathbf{3 . 1 8}$ & $\mathbf{0 . 0 0}$ \\
H11 & CR $\rightarrow$ CL & $\mathbf{0 . 2 9}$ & $\mathbf{3 . 0 9}$ & $\mathbf{0 . 0 0}$ \\
\hline
\end{tabular}

Note: $\mathrm{p}$-value $<0.05 ; \mathrm{p}$-value $<0.10$

Constructs: AS (assurance), CI (corporate image), PR (personalization), RE (reliability), SN

(sincerity), TAN (tangibility), SB (social bonds), STB (structural bonds), CR (corporate

reputation), FB (financial bonds), IEB (Islamic ethical behaviour), CL (customer loyalty)

\section{Discussion}

Significantly, this study discovers that corporate image impacts on corporate reputation and customer loyalty differ significantly between Saudi Arabia and Malaysia. Takaful in Saudi Arabia is based on a cooperative model that necessitates Shari'ah compliance, although the cooperative insurance industry regulators do not specify comprehensive procedures. Thus, the practices tend to differ among insurance operators. The current study's findings may provide new insights to other market settings, especially those with similar features and regulatory frameworks. Both Malaysian and Saudi Arabian customers are at the same pace in identifying reliability, Islamic ethical behaviour, and structural bonds towards gauging corporate image. Reliability, subsequently, needs to be concurred by Takaful operators in both countries, specifically with innovation and technology, to better the interaction between Takaful operators and participants, maximising efficiencies and providing a competitive edge.

Islamic ethical values are essential elements towards gearing a good image, especially for an Islamic organization, to be operating daily within Islamic principles. Islamic finance must observe ethical norms and values founded on Shari'ah; it offers fair and transparent transactions, mutual assistance, and eliminates hardship (Haniffa and Hudaib, 2007). Takaful, coined as ethical, prohibiting the elements of usury, uncertainty, gambling and other components forbidden in Islam, creates the atmosphere of a caring society while promoting solidarity (Kasim et al., 2016). 
Structural bonds are another ingredient that is vital for both Malaysian and Saudi Arabian customers, which affects the corporate image. Berry (1995) indicated that structural bond is very pertinent as it is built on institutional structures, rules, governance, and valid norms or policies (Berry, 1995). Both Malaysian and Saudi Arabian Takaful operators need to structure the products to be inclusive for all races and beliefs, even though they should conform to Islam's values. Simultaneously, Takaful customers should understand the differences between conventional insurance and Takaful in which risk and protection are mutually shared. More importantly, both countries have addressed Takaful operators' importance to uphold Shari'ah principles and values in their business practices. Furthermore, Malaysia's Takaful sector may not significantly impact the conventional insurance system, despite Malaysia being a Muslim country implementing Shari'ah principles in its banking and finance industry (Shaikh and Noordin, 2018). This is possibly due to the non-stimulating financial performance experienced by the Islamic financial institutions in Muslim counterparts, with an unsound corporate governance structure in the Takaful industry (Eldaia et al., 2020).

De Leaniz and Rodríguez (2016) emphasized that tangible attributes, including human capital, facilities, digital touch, and personalized customer service, should be given the biggest concern for organizations to stay competitive in the industry. Takaful operators need to access and continuously monitor their reputations to ensure appropriate measures for further improvement. The Malaysian Takaful operators, for example, need to concentrate on the aspects of tangibility, personalization, as well as the impact of the corporate image towards customer loyalty. Undeniably, they need to construct suitable products that fulfil their needs, as awareness alone is insufficient to overcome their challenges.

Nonetheless, corporate image affects corporate reputation in the Malaysian context, but not in Saudi Arabia. When a customer experiences good quality services, he/she will perceive the organization positively. Therefore, the positive image of a Takaful operator significant for a worthy reputation. This finding is similar to Lai's (2019) result of the analysis in which he discovered that a hotel image is an essential construct towards building a reputation. This gratified experience helped build a good reputation for hotels, forming a pledge or a commitment towards positive encounters and enhancing customer loyalty.

On the other hand, Saudi Arabian customers perceived reliability, assurance, Islamic ethics, structural bonds and financial bonds to be relevant factors that may contribute to corporate image and the effect of corporate reputation on customer loyalty. Unfortunately, these two elements, including assurance and financial bonds, are insignificant in Malaysian customers. Assurance is 
vital to understand perceived quality as it involves communicating their specialized skills and proficiencies to customers. Saudi Arabia's customers perceived Takaful operators as professional concerning their assigned task, providing feedback and having a positive attitude. Thus, they are confident in the services rendered by them. Financial bonds are also another significant constituent of relationship management that facilitates buying behaviour, similar to Liang and Wangs' (2007) findings.

Hence, Takaful operators need to identify customers prone to such decisions, although they need to invest more in relationship management technologies. Nevertheless, such efforts seem to provide short-term advantages to many organizations, including Takaful operators. Thus, they need to combine other competitive advantages or other related strategies to hold a sustainable business operation. The industry needs to continue designing and delivering solutions that meet actual demands and offer customers a positive experience to remain competitive. Principally, the Takaful operators must address the needs of both Muslims and non-Muslims, especially the lower-income group, by offering uniqueness of products without duplicating current insurance products and services. According to the research, Takaful operators from Malaysia and Saudi Arabia need to put maximum effort towards customer loyalty by bringing both dimensions of service quality and relationship marketing in compliance with Islamic business transaction principles. The findings of specific dimensions of service quality and relationship marketing will contribute to customer perception of corporate image and reputation in Takaful. This study explores some of the PAKSERV dimensions of service quality (Rajpoot, 2004) and relationship marketing by adding an essential component: Islamic ethical behaviour (Salleh et al., 2013), identifying its impact on corporate image. Simultaneously, the study attempts to recognize the impact of corporate image on corporate reputation and concomitantly influence corporate image on customer loyalty.

\section{Conclusion}

Indeed, customers are very crucial in any business, including Takaful products and services. In this theoretical study, we have endeavored to explore the effect of the corporate image from the standpoints of two crucial components of services; perceived service quality and relationship marketing. This study suggests a common topic, nevertheless with a bit of a twist due to the prevailing research gaps, particularly the integration of both components and its impact on corporate image and its influence on corporate reputation and customer loyalty. More importantly, this study examines the essentials of Islamic ethical values embedded in relationship 
marketing, particularly in all Islamic institutions, including the Takaful operators. Furthermore, it is found that customer experience on the service quality and relationship marketing significantly influence corporate image. Therefore, this suggests that the Takaful operators need to emphasize service quality and relationship marketing components to enhance customer loyalty, specifically through corporate image and corporate reputation.

The current study came up with few limitations. However, future research studies can focus on numerous aspects, including the proposed research model tested in Takaful Malaysian and Saudi Arabian can be replicated in other contexts. Second, the current study reveals the critical role of corporate image in forming corporate reputation. Future research could be focussed on the importance of other emotional or affective variables that may be involved in determining corporate reputation. Finally, future studies can be carried with another cultural perspective to have more diversified socio-economic implications. This will provide a longitudinal vision of the antecedents of corporate reputation and customer loyalty by contributing to developing theories about the effect of socio-economic changes on the drivers of corporate reputation and customer loyalty.

\section{References}

Abdullah, A. A., and Wan, H. L. (2013), "Relationships of non-monetary incentives, job satisfaction and employee job performance", International Review of Management and Business Research, Vol. 2 No. 4, pp. 1085-1091.

Abdur Rehman, M., Osman, I., Aziz, K., Koh, H., and Awais, M. (2019), "Get connected with your Takaful representatives: Revisiting customer loyalty through relationship marketing and service quality", Journal of Islamic Marketing, Vol. 11 No. 5, pp. 1175-1200.

Ab Rahim, F., and Amin, H. (2011), "Determinants of Islamic insurance acceptance: an empirical analysis", International Journal of Business and Society, Vol. 12 No. 2, pp. 3754.

Alkhan, A.M. and Hassan, M.K. (2020a), "Takaful operators: analysing segregated accounts between operator/participants", Journal of Islamic Accounting and Business Research, Vol. 11 No. 9, pp. 1649-1664.

Alkhan, A.M. and Hassan, M.K. (2020b), "How do Takaful operators choose which model to adopt? A case study from the Kingdom of Bahrain”, Journal of Islamic Accounting and Business Research, Vol. 11 No. 9, pp. 1677-1688.

Al-Mubarak, Z. Hamed, A.B. and Al-Mubarak, M. (2019). Impact of corporate social responsibility on bank's corporate image. Social Responsibility Journal, Vol. 15, No 5, pp. 710-7.

Amin, H. (2012), “An analysis on Islamic insurance participation”, Jurnal Pengurusan (UKM Journal of Management), Vol. 34, pp. 11-20.

Anouze, A.L.M. and Alamro, A.S. (2019), "Factors affecting intention to use e-banking in Jordan”, International Journal of Bank Marketing, Vol. 38 No. 1, pp. 86-11222 
Al-Tamimi, A., and Al-Amiri, A. (2003), "Analysing service quality in the UAE Islamic banks", Journal of Financial Services Marketing, Vol. 8 No. 2, pp. 119-132.

Alessandri, S.W. (2001). Modeling corporate identity: a concept explication and theoretical explanation. Corporate Communications: An International Journal , Volume 6 (4): 173

Alwi, S., and Ismail, S. A. (2013), "A framework to attain brand promise in an online setting”, Marketing Intelligence and Planning, Vol. 31 No. 5, pp. 557-578.

Aslam, W., and Farhat, K. (2020), "Impact of after-sales service on consumer behavioural intentions". International Journal of Business and Systems Research, Vol. 14 No. 1, pp. 44-55.

Bank Negara Malaysia (2019). Takaful Operational Framework. https://www.bnm.gov.my/documents/20124/948107/PD+TOF+26+June+2019.pdf/4ab1b 034-3ea5-3ef2-d5aa-6f5b5d682fca?t=1594083517627 (Accessed on 31 December 2020)

Balmer, J. M., van Riel, C. B., Markwick, N., and Fill, C. (1997). Towards a framework for managing corporate identity. European Journal of marketing, Vol. 31 No. 5/6, pp. 396409.

Balmer, J.M.T. and Greyser, S.A. (2006), "Corporate marketing: Integrating corporate identity, corporate branding, corporate communications, corporate image and corporate reputation", European Journal of Marketing, Vol. 40 No. 7/8, pp. 730-741.

Becker-Olsen, K. L., Cudmore, B. A., and Hill, R. P. (2006), "The impact of perceived corporate social responsibility on consumer behavior", Journal of Business Research, Vol. 59 No. 1, pp. 46-53.

Berry, L.L. (1995), "Relationship marketing of services-growing interest, emerging perspectives". Journal of the Academy of marketing science, Vol. 23 No. 4, pp. 236-245.

Bravo, R., Montaner, T. and Pina, J.M. (2009), "The role of bank image for customers versus non-customers", International Journal of Bank Marketing, Vol. 27 No. 4, pp. 315-334.

Chandon, P., Wansink, B., and Laurent, G. (2000), "A benefit congruency framework of sales promotion effectiveness", Journal of Marketing, Vol. 64 No. 4, pp. 65-81.

Chattalas, M., Kramer, T., and Takada, H. (2008). "The impact of national stereotypes on the country of origin effect". International Marketing Review, 25(1), 54-74.

Chiu, C. M., Hsu, M. H., Sun, S. Y., Lin, T. C., and Sun, P. C. (2005), "Usability, quality, value and e-learning continuance decisions", Computers and Education, Vol. 45 No. 4, pp. 399-416.

Coelho, P. S., and Henseler, J. (2012), "Creating customer loyalty through service customization", European Journal of Marketing, Vol. 46 No. 3/4, pp. 331-356.

Dabholkar, P. A., Thorpe, D. I., and Rentz, J. O. (1996), "A measure of service quality for retail stores: scale development and validation", Journal of the Academy of marketing Science, Vol. 24 No. 1, pp. 3-16.

Davies, G., Chun, R., De Silva, R. V. , and Roper, S. (2004). A corporate character scale to assess employee and customer views of organization reputation. Corporate Reputation Review, 7(2), 125-146

De Leaniz, M.G. and del Bosque, I.R. (2016), "Corporate Image and Reputation as Drivers of Customer Loyalty", Corporate Reputation Review, Vol. 19 No. 2, pp. 166-178.

Dibb, S., and Meadows, M. (2001), "The application of a relationship marketing perspective in retail banking”, Service Industries Journal, Vol. 21 No. 1, pp. 169-194. 
Dowling G. R. (2004). Corporate Reputations: Should You Compete on Yours? California Management Review. Vol 46 (3):19-36.

Dusuki, A. W. (2008). A critical appraisal on the challenges of realizing maqasid alShari'ah in Islamic banking and finance. In Islamic finance : an old skeleton in a modern dress. Kuala Lumpur: International Shari'ah Research Academy for Islamic Finance (ISRA).

Eldaia, M., Hanefah, M. B. M., Marzuki, A. B., and Shatnawi, S. (2020). Takaful in Malaysia: Emergence, Growth, and Prospects. In Handbook of Research on Theory and Practice of Global Islamic Finance (pp. 681-702). IGI Global.

Ennew, C., Waite, N., and Waite, R. (2013). Financial services marketing: An international guide to principles and practice. Routledge.

Endara, Y.M., Asbi B.A., and Ab Yajid, M.Sh. (2019), "The influence of culture on service quality leading to customer satisfaction and moderation role of type of bank", Journal of Islamic Accounting and Business Research, Vol. 10 No. 1, pp. 134-154.

Fontaine, R. and Khaliq, A. (2013). Strategic Management from an Islamic perspective. Singapore: John Wiley

Melewar, T.C., Foroudi, P., Gupta, S., Kitchen, P.J. and Foroudi, M.M. (2017), "Integrating identity, strategy and communications for trust, loyalty and commitment", European Journal of Marketing, Vol. 51 No. 3, pp. 572-604.

Gray, E., and Balmer, J. (1998), "Managing Corporate Image and Corporate Reputation", Long Range Planning, Vol. 31, No. 5, pp. 695 - 702.

Gwinner, K. P., Gremler, D. D., and Bitner, M. J. (1998), "Relational benefits in services industries: the customer's perspective", Journal of the academy of marketing science, Vol. 26 No. 2, pp. 101-114.

Hair, J., Hollingsworth, C. L., Randolph, A. B., and Chong, A. Y. L. (2017), “An updated and expanded assessment of PLS-SEM in information systems research", Industrial Management and Data Systems, Vol. 117 No. 3, pp. 442-458.

Hair, J. F., Risher, J. J., Sarstedt, M., and Ringle, C. M. (2019), "When to use and how to report the results of PLS-SEM", European Business Review, Vol. 31 No. 1, pp. 2-24.

Hanafi, S. N. I. M., Maulan, S. B., and Hamid, S. N. A. (2020), "Service Quality of Islamic Banks: A Cultural Perspective", International Journal of Islamic Banking and Finance Research, Vol. 4 No. 2, pp. 11-21.

Haniffa, R., and Hudaib, M. (2007), "Locating audit expectations gap within a cultural context: The case of Saudi Arabia", Journal of International Accounting, Auditing and Taxation, Vol. 16 No. 2, pp. 179-206.

Handelman, J. M., and Arnold, S. J. (1999). The role of marketing actions with a social dimension : appeals to the institutional environment. Journal of Marketing, 63(July ), 3348.

Haron, R., Abdul Subar, N. and Ibrahim, K. (2020), "Service quality of Islamic banks: satisfaction, loyalty and the mediating role of trust", Islamic Economic Studies, Vol. 28 No. 1, pp. 3-23.

Hassan, R., Salman, S.A., Kassim, S. and Majdi, H. (2018). Awareness and Knowledge of Takaful in Malaysia: A Survey of Malaysian Consumers. International Journal of Business and Social Science, Vol. 9 No. 11, pp. 45-53.

Hassan, H.A. (2019). "Takaful models: origin, progression and future", Journal of Islamic Marketing, Vol. 11 No. 6, pp. 1801-1819.

Hassan, H.A., and Abbas, S.K. (2019), "Factors influencing the investors' intention to adopt Takaful (Islamic insurance) products". Journal of Islamic Marketing. Vol. 11 No. 1, pp. $1-13$. 
Hassan, M.K., Paltrinieri, A., Dreassi, A., Khan, A., and Bahoo, S. (2020), "A bibliometric review of Takaful literature", International Review of Economics and Finance. Vol. 69 No. 1, pp. 389-405.

Hatch, M. J., and Schultz, M. (2003). Bringing the corporation into corporate branding. European Journal of Marketing, Vol. 371 No. 7/8, pp. 1041-1064

Hayward, R. (2005), Maintaining Corporate Image, Prentice Hall, Upper Saddle River, NJ.

Helm, S., and Tolsdorf, J. (2013), "How does corporate reputation affect customer loyalty in a corporate crisis?" Journal of Contingencies and Crisis Management, Vol. 21 No. 3, pp. $144-152$.

Hemrit, W. (2020), "Determinants driving Takaful and cooperative insurance financial performance in Saudi Arabia", Journal of Accounting and Organizational Change, Vol. 16 No. 1, pp. 123-143.

Hofstede, G. (2001). Culture's consequences: Comparing values, behaviors, institutions and organizations across nations. Sage publications.

Hsieh, Y. C., Chiu, H. C., and Chiang, M. Y. (2005), "Maintaining a committed online customer: A study across search-experience-credence products", Journal of Retailing, Vol. 81 No. 1, pp. 75-82.

Huang, C.C., Fang, S.C., Huang, S.M., Chang, S.C. and Fang, S.R. (2014), "The impact of relational bonds on brand loyalty: the mediating effect of brand relationship quality", Managing Service Quality: An International Journal, Vol. 24 No. 2, pp. 184-204.

Hussain, S., Melewar, T. C., Priporas, C. V., and Foroudi, P. (2020), "Examining the effects of advertising credibility on brand credibility, corporate credibility and corporate image: a qualitative approach", Qualitative Market Research, Vol. 23 No. 4, pp. 549-573.

Kantakji, M.H., Hamid, B.A., and Alhabshi, S. O. (2020). "What drives the financial performance of general Takaful companies?", Journal of Islamic Accounting and Business Research. Vol. 11 No. 6, pp. 1301-1322.

Kotler, P. and Barich, H. (1991) A Framework for Marketing Image Marketing Image Management. Sloan Management Review, 32, 94-104.

Kant, R., Jaiswal, D., and Mishra, S. (2017), "The investigation of service quality dimensions, customer satisfaction and corporate image in Indian public sector banks: An application of Structural Equation Model (SEM)", Vision, Vol. 21 No. 1, pp. 76-85.

Kant, R. and Jaiswal, D. (2017), "The impact of perceived service quality dimensions on customer satisfaction: An empirical study on public sector banks in India", International Journal of Bank Marketing, Vol. 35 No. 3, pp. 411-430

Kashif, M., Abdur Rehman, M., and Pileliene, L. (2016), "Customer perceived service quality and loyalty in Islamic banks", The TQM Journal, Vol. 28 No. 1, pp. 62-78.

Kasim, N., Htay, S. N. N., and Salman, S. A. (2016), "The religious perspective of Takaful as ethical insurance", Mediterranean Journal of Social Sciences, Vol. 7 No. 4, pp. 96-104.

Kim, J.J., Steinhoff, L., and Palmatier, R.W. (2020), "An emerging theory of loyalty program dynamics", Journal of the Academy of Marketing Science, pp. 1-25.

Kotler, P., and Gertner, D. (2002), "Country as brand, product, and beyond: A place marketing and brand management perspective", Journal of brand management, Vol. 9 No. 4, pp. 249-261.

Laeheem, K. (2018), "Approaches to promoting Islamic ethics in adherence to the faith among Thai Muslim youths in Pattani province, Southern Thailand", Kasetsart Journal of Social Sciences, pp. 1-6.

Lai, I.K.W. (2019), "Hotel image and reputation on building customer loyalty: An empirical study in Macau". Journal of Hospitality and Tourism Management, Vol. 38, pp. 111-121. 
Lee, M.-S. and Han, S.-L. (2019), “The effects of relationship bonds on bank employees' psychological responses and boundary-spanning behaviors: An empirical examination of the JD-R model", International Journal of Bank Marketing, Vol. 38 No. 3, pp. 578-599.

Liang, C. and Wang, W. (2007), "An insight into the impact of a retailer's relationship efforts on customers' attitudes and behavioral intentions", International Journal of Bank Marketing, Vol. 25 No. 5, pp. 336-366.

Lin, L., Lu, C. (2010), The influence of corporate image, relationship marketing, and trust on purchase intention: the moderating effects of word-of-mouth. Tourism Review, 65(3), 1634.

Maizaitulaidawati, M. H., and Asmak, A. R. (2016), "Do Muslims intend to participate in Islamic insurance?: Analysis from theory of planned behaviour", Journal of Islamic Accounting and Business Research, Vol. 7 No. 1, pp. 42-58.

Matsawali, M. S., Abdullah, M. F., Yeo, C. P., Abidin, S. Y., Zaini, M. M., Ali, H. M., and Yaacob, H. (2012), "A study on Takaful and conventional insurance preferences: The case of Brunei”, International Journal of Business and Social Science, Vol. 3 No.22, pp. 163-176.

Md Husin, M. and Haron, R. (2020), "Takāful demand: a review of selected literature", International Journal of Islamic Finance, Vol. 12 No. 3, pp. 443-455.

Melewar, T.C., Foroudi, P., Gupta, S., Kitchen, P.J. and Foroudi, M.M. (2017), "Integrating identity, strategy and communications for trust, loyalty and commitment", European Journal of Marketing, Vol. 51 No. 3, pp. 572-604.

Milan, G., Slongo, L., Eberle, L., De Toni, D. and Bebber, S. (2018), "Determinants of customer loyalty: a study with customers of a Brazilian bank", Benchmarking: An International Journal, Vol. 25 No. 9, pp. 3935-3950.

Mohy-Ul-Din, S., Samad, S., Abdur Rehman, M., Ali, M.Z. and Ahmad, U. (2019), “The mediating effect of service provider expertise on the relationship between institutional trust, dispositional trust and trust in Takaful services", International Journal of Islamic and Middle Eastern Finance and Management, Vol. 12 No. 4 pp. 509-522.

Muhamad, N., and Mizerski, D. (2010), “The constructs mediating religions' influence on buyers and consumers", Journal of Islamic Marketing, Vol. 1 No. 2, pp. 124-135.

Muhamat, A. A., and McIver, R. (2019), "Linking governance qualities and stewardship attributes: findings from Malaysian Takaful operators", Journal of Islamic Accounting and Business Research, Vol. 10 No. 5, pp. 736-755.

Munusamy, J., Chelliah, S. and Mun, H.W. (2010). Service quality delivery and its impact on customer satisfaction in the banking sector in Malaysia. International Journal of Innovation, Management and Technology. 1. 398-404

Nam, S. (2008), "The impact of culture on the framework of customer value, customer satisfaction and customer loyalty", dissertation, Golden Gate University, San Francisco, CA.

Nguyen, N., and Leblanc, G. (1998), “The mediating role of corporate image on customers' retention decisions: an investigation in financial services", International Journal of Bank Marketing, Vol. 16 No. 2, pp. 52-65.

Nguyen, N., and Leblanc, G. (2001), "Corporate Image and Corporate Reputation in Customers' Retention Decisions in Services", Journal of Retailing and Consumer Services, Vol. 8 No. 4, pp. 227-236.

Oliver, R. (1999), "Whence consumer loyalty”, Journal of Marketing, Vol. 63 No. 4, pp. 33-44.

Olorunniwo, F., Hsu, M. K., and Udo, G. J. (2006), "Service quality, customer satisfaction, and behavioral intentions in the service factory", Journal of Services Marketing, Vol. 20 No. 1, pp. 59-72. 
Omar, M., Williams, R. L., and Lingelbach, D. (2009). Global brand market-entry strategy to manage corporate reputation", Journal of Product and Brand Management, Vol. 18, pp. 177-187.

Osman, I., Abdullah, K., Haque, A.K.M., Abdullah, N.I. and Abdur Rehman, M. (2018). Incorporating Institutional Theory of Corporate Image towards Customer Loyalty of Islamic banks. Malaysian Journal of Consumer and Family Economics, Vol 21 (Special Issue 2), pp 153-173

Parasuraman, A., Zeithaml, V. A., and Berry, L. L. (1988), "Servqual: A multiple-item scale for measuring consumer perc", Journal of Retailing, Vol. 64 No. 1, pp. 12-40.

Peterson, R. A., and Kim, Y. (2013), "On the relationship between coefficient alpha and composite reliability", Journal of Applied Psychology, Vol. 98 No. 1, pp. 194-198.

Peltier, J. W., and Westfall, J. (2000), "Dissecting the HMO-benefits managers relationship: What to measure and why", Marketing Health Services, Vol. 20 No. 2, pp. 4-13.

Piercy, N. F., and Lane, N. (2007), "Ethical and moral dilemmas associated with strategic relationships between business-to-business buyers and sellers" Journal of Business Ethics, Vol. 72 No. 1, pp. 87-102.

Raajpoot, N. (2004), "Reconceptualizing service encounter quality in a non-western context", Journal of Service Research, Vol. 7 No. 2, pp. 181-201.

Raza, S.A., Ahmed, R., Ali, M. and Qureshi, M.A. (2019), "Influential factors of Islamic insurance adoption: an extension of theory of planned behavior", Journal of Islamic Marketing, Vol. 11 No. 6, pp. 1497-1515.

Rodríguez, C. M., and Wilson, D. T. (2002), "Relationship bonding and trust as a foundation for commitment in US-Mexican strategic alliances: A structural equation modeling approach", Journal of International Marketing, Vol. 10 No. 4, pp. 53-76.

Ruiz, B., García, J.A., and Revilla, A.J. (2016), "Antecedents and consequences of bank reputation: a comparison of the United Kingdom and Spain”. International Marketing Review, Vol. 33, pp.781-805.

Salleh, M.C.M., Abdullah, N.I. and Razali, S.S. (2013), "Measuring Takaful Agents' Understanding Towards The Objectives and Concepts of Takaful", Journal of Islamic Finance, Vol. 2 No. 1, pp. 20-30.

Saleh, M., Quazi, A., Keating, B. and Gaur, S. (2017), "Quality and image of banking services: a comparative study of conventional and Islamic banks", International Journal of Bank Marketing, Vol. 35 No. 6, pp. 878-902

Salman, S.A., and Hassan, R. (2020), "Motivating factors for consumers to participate in takāful: a survey by Indian insurance policyholders", Journal of Islamic Accounting and Business Research, Vol. 11 No. 9, pp. 1871-1888.

Saunders, S. G. (2008), "Measuring and applying the PAKSERV service quality construct: Evidence from a South African cultural context", Managing Service Quality: An International Journal, Vol. 18 No. 5, pp. 442-456.

Semeijn, J., Van Riel, A. C., and Ambrosini, A. B. (2004), "Consumer evaluations of store brands: effects of store image and product attributes", Journal of Retailing and Consumer Services, Vol. 11 No. 4, pp. 247-258.

Shaikh, I. M., and Noordin, K. (2018), “Customer's Attitude towards Diminishing Partnership Home Financing: A Comparative Study of Malaysia and Pakistan”, Middle East Journal of Business, Vol. 55 No. 6093, pp. 1-8.

Shammout, A.B. (2018), "An empirical investigation of relational bonds on attitudinal and behavioral customer loyalty for Arabic luxury hotel customers". International Journal of Hospitality and Tourism Administration, pp. 1-21. 
Shamma, H.M. (2012), "Toward a Comprehensive Understanding of Corporate Reputation: Concept, Measurement and Implications", International Journal of Business and Management, Vol. 7 No. 16 pp. 151-169.

Shukor, S. (2020), "Trust in Takaful agents: antecedents and consequences", Journal of Islamic Accounting and Business Research, Vol. 11 No. 6, pp. 1161-1174.

Sofi, M.R., Bashir, I., Parry, M.A. and Dar, A. (2020), "The effect of customer relationship management (CRM) dimensions on hotel customer's satisfaction in Kashmir", International Journal of Tourism Cities, Vol. 6 No. 3, pp. 601-620.

Suki, N. M., and Suki, N. M. (2019), "Investigating The Measurement of Consumers' Electronic Word-of-Mouth (E-WOM), Intrinsic and Extrinsic Motives, and Satisfaction of Islamic Insurance (Takaful)", Jurnal Komunikasi: Malaysian Journal of Communication, Vol. 35 No. 2 pp. 431-447.

Sureshchandar, G. S., Rajendran, C., and Anantharaman, R. N. (2002), "The relationship between service quality and customer satisfaction-a factor specific approach", Journal of Services Marketing, Vol. 16 No. 4, pp. 363-379.

Taleghani, M., Gilaninia, S., and Mousavian, S. J. (2011), "The role of relationship marketing in customer orientation process in the banking industry with focus on loyalty (Case study: Banking industry of Iran)", International Journal of Business and Social Science, Vol. 2 No. 19, pp. 155-166.

Tran, M.A. and Nguyen, B., Melewar, T. C. and Bodoh, J. (2015) Exploring the corporate image formation process. Qualitative Market Research: An International Journal, 18 (1). pp. 86114.

Van Riel, A. and Lemmink, J. and Ouwersloot, H. (2001). Consumer Evaluations of Service Brand Extensions. Journal of Service Research, 3. pp. 220-231

Walsh, G., Mitchell, V. W., Jackson, P. R., and Beatty, S. E. (2009), "Examining the antecedents and consequences of corporate reputation: A customer perspective", British Journal of Management, Vol. 20 No. 2, pp. 187-203.

Wang, X., Wei, Y. C., Egri, C. P., and Lin, C. Y. Y. (2014), "Do corporate social responsibility practices yield different business benefits in eastern and western contexts?", Chinese Management Studies, Vol. 8 No. 4, pp. 556-576.

Westbrook, R. A. (1981), "Sources of consumer satisfaction with retail outlets", Journal of Retailing, Vol. 57 No. 3, pp. 68-85.

Worcester, Robert. (2009). Reflections on corporate reputations. Management Decision. 47. 573589.

Yoganathan, D., Jebarajakirthy, C., and Thaichon, P. (2015), “The influence of relationship marketing orientation on brand equity in banks", Journal of Retailing and Consumer Services Vol. 26, pp. 14-22.

Yoon, Y., Gürhan-Canli, Z., and Schwarz, N. (2006), "The effect of corporate social responsibility (CSR) activities on companies with bad reputations", Journal of Consumer Psychology, Vol. 16 No. 4, pp. 377-390.

Yusoff, N. M. A. N. (2002). Islam and Business. Selangor: Pelanduk Publications (M) Sdn. Bhd. 